\title{
Measuring Employee Performance of Shuttle Cock Industry in Surakarta, Indonesia
}

\author{
Ratih Indriyani ${ }^{1^{*}}$, Hendro Prakoso Handjaya ${ }^{1}$, and Ayoub Gougui ${ }^{2}$ \\ ${ }^{1}$ Department of Management, Faculty of Business and Economics, Petra Christian University, \\ Jl. Siwalankerto 121-131, Surabaya 60236, Indonesia \\ ${ }^{2}$ School of Business Management, College of Business, Universiti Utara Malaysia
}

\begin{abstract}
Employees are the core of ongoing organizational activities. In the industrial cycle, employees are coming from adjacent regions. Social support is needed to have motivation at work. Motivation to work will have an impact on work results. This study aims to analyze social support for employee performance with work motivation as an intervening variable in the shuttlecock industry in Pringgolayan Surakarta, Indonesia. Previous research shows that social support has an influence on employee motivation at work. Other studies explain that motivation can improve employee performance. This study uses a quantitative method with a sample of 100 respondents. The sample is determined by the purposive sampling method. Respondents are employees of the shuttlecock industry, who had worked for at least 3 mo.. This study uses SmartPLS 3.0 as a data analysis technique. The results of this study indicate that working conditions have a significant effect on work motivation, social support has a significant effect on work motivation and social support has a significant effect on employee performance. Research also shows that work motivation has a significant influence on employee performance. Work motivation among shuttlecock industry employees still needs to be improved so that its performance is improved. Aspects of social support are friends and superiors, for that the leadership must provide support to increase employee work motivation.
\end{abstract}

Keywords: Individual performance, social support, task, work motivation, workplace.

\section{Introduction}

Human resources are factors that need to be managed properly by the company. The management of human resources is carried out so that human resources become competent so as to improve the performance of employees and the company. Noah and Steve, in their research, stated that to run a smooth, effective and efficient organization, human resources are the most valuable and much needed by organizations [1].

An employee will be able to carry out the work well, so as to achieve an op-timal result if one of them is supported by social support. Social support also plays a role in increasing or decreasing work motivation and employee performance. Social support is the presence of other people who can make individuals believe that they are loved, cared for, and are part of a social group, namely family members, colleagues, and close friends [2]. Smet says that

\footnotetext{
*Corresponding author: ranytaa@petra.ac.id
} 
social support is a function of social ties, and social ties illustrate the general quality level of in-personal relationships [3].

Based on the results of the interviews, the employees in the shuttlecock industry in Pringgolayan Village, Surakarta, showed that social support from friends and family became an encouragement when employees took a lot of work (Interview with several employees on November 15, 2018). Social support from friends and family becomes a consideration in determining how many shuttlecocks will be worked on. When employees get positive support from family and coworkers, they will take more work than before, and vice versa, when they get negative support, employees will not be enthusiastic in working so that they cannot complete the work.

Achieving good performance without getting social support is difficult to materialize; by getting social support, employees are able to work more passionately, better because basically, humans are social beings who need support from others. Social support is a form of interpersonal relationships with people around them, in which there is assistance in the form of empathy given through the process of communication and social contact. Eventually, there will be pleasure and appreciation from people who get help and feelings that are being watched by people who receive help or support. The involvement of family, friends and or work can provide support, especially for those who have special needs and are not found in work or workplaces. Support can be direct or indirect. Social support affects psychological aspects so that employees can work more calmly, loyally and motivated to work, so that good employee performance is created [2].

In addition to these two factors, motivation also plays a role in increasing or decreasing the performance of the Shuttlecock industry. Motivation is a de-terminant that is important for individual achievement. Motivation is a concept that describes the strengths that exist in employees who start and direct behavior. Employees with enthusiastic behavior are the result of stronger levels of motivation, and conversely, employees with low morale are the result of a lack of motivation to work [4].

According to Mensah and Tawiah motivation is defined as a process that takes into account the intensity of the individual, direction, and persistence to achieve goals [5]. Motivation has psychological and managerial significance. The psychological meaning of motivation refers to the internal mental state of a person related to the initiation, direction, perseverance, intensity, and cessation of behavior. The meaning of managerial motivation is related to the activities of managers and leaders encouraging others to produce the results desired or outlined by the organization or by managers.

Based on interviews, the shuttle-cock industry in Pringgolayan Village, Surakarta, Indonesia showed that they were motivated to work, one of which was getting monthly salaries and more flexible work (Interviews with Arima-tea, Marman, and Yayak, owners of the Adamputrat shuttlecock business on October 15, 2018). Work was done. Shuttlecock industry is flexible because there are no restrictions on how many employees must complete the work, and there is no deadline for completion of work done when, but that does not mean employees can be lazy because the more that is done, the more employees receive.

The relationship of work motivation and employee performance in Jayaweera's study is found that work motivation has a positive influence on performance, meaning that when employees have high motivation causes employees to be able to optimize their abilities at work [6]. These conditions cause the results of employee work to increase. Work motivation is an internal encouragement from employees so that when work motivation is high, employees have a strong commitment and are not easily discouraged in facing various problems at work so that it increases work results. Even though someone has a lot of skills, knowledge, and abilities. The person cannot do a good job until the person can be motivated, so motivation is important in improving employee performance. 


\section{Literature review}

\subsection{Social support}

Social support is the presence of other people who can make individuals believe that they are loved, cared for, and are part of social groups, namely family, coworkers and close friends [2]. Smet says that social support is a function of social ties, and social ties illustrate the general level of quality of interpersonal relationships [3]. Albrecht and Adleman define social support as verbal and non-verbal communication between the recipient and the provider to reduce uncertainty about the situation, self, other people, or relationships and functions to enhance the perception of one's self-control in one- only life experience [7].

Social support, according to Kumalasari and Ahyani is one function of social ties, and social ties illustrate the general level of quality of interpersonal relationships [8]. Ties and friendships with others are considered aspects that provide emotional satisfaction in an individual's life. From some of the opinions above, it can be concluded that social support is positive assistance or support given by certain people to individuals towards their lives as well as in certain social environments so that the receiving individual feels cared for, valued, respected, and loved.

\subsection{Work motivation}

Basic word motivation (motivation) is a motive that means encouragement, cause, or reason for someone to do something. Therefore, motivation can mean a condition that encourages or becomes a cause for someone to do something action or activity, which takes place consciously [9]. According to Wursanto needs are generating and driving behavior [10]. This means if there is a shortage of needs, people will be more sensitive to motivation. Thus, needs are closely related to the shortcomings experienced by someone. This deficiency can be physiological (food, clothing, and living places), psychological (recognition or appreciation), and social (group).

If the various needs can be fulfilled or the various deficiencies can be overcome, it will give encouragement to someone to perform better. Therefore, the main motivation for someone to work in a company is to meet these various needs. An employee will be motivated to work earnestly if he feels given an opportunity to develop his achievements, feels friendship in the work environment, and feels there is an opportunity to occupy a position so that he can advise others. In other words, if the employee's needs are met, then the employee will tend to behave as desired by the company.

The need for high achievers in employees will encourage employees to achieve success. Employees will struggle to fulfill their ambitions personally rather than achieve success in the form of company awards. Employees are always better and more efficient over time.

\subsection{Employee performance}

According to Torang performance is the quatity and quality of the work of individuals or groups within the company in carrying out basic tasks and functions which are guided by norms, standard operating procedures, criteria, and measurements that have been set or applicable in the company [11]. According to Sedarmayanti performance means the work of a worker, a management process, or an organization as a whole, where the work results must be able to show concrete evidence and can be measured (compared with predetermined standards) [12]. In the opinion of the experts above, it can be concluded that employee performance is the result of the work achieved by an employee in carrying out their duties. 


\subsection{Hypothesis development}

\subsubsection{Social support and work motivation}

Social support is needed by the individual in dealing with others in order to carry out his life in the community. Smet says that social support is one function of social ties [3]. The social ties describe the general level of quality of interpersonal relationships. The definition of social support is defined by Smet as an interpersonal transaction involving one or more aspects consisting of emotional support, appreciation, instrumental, and information [3]. the availability of social support will make individuals feel loved, cared for, valued, and become part of the group.

Research conducted by Rahmadita found that there was a very significant positive relationship between social support and job motivation for employees [13]. When individuals receive full social support for what is done, the individual will feel more comfortable working so that the individual will show maximum work performance, which in turn will increase the motivation to work from the individual.

H1: Social support influences the work motivation of shuttlecock industry employees in Pringgolayan Village, Surakarta.

\subsubsection{Social support and employee performance}

Achieving good performance without getting social support is difficult to materialize. By getting social support employees are able to work more passionately, better because basically, humans are social beings who need support from others. Social support is a form of interpersonal relationships with people around them, in which there is assistance in the form of empathy given through the process of communication and social contact. Eventually, there will be pleasure and appreciation from people who get help and feelings that are being watched by people who receive help or support. The involvement of family, friends and or work can provide support, especially for those who have special needs and are not found in work or workplaces. Support can be direct or indirect. Social support affects psychological aspects so employees can work more calmly, loyally and motivated to work, so that good employee performance is created.

Raeda's research results show that social support from colleagues has a significant effect on performance [14]. According to Raeda, social support from coworkers is able to increase the level of employee performance [14]. H2: Social support influences the performance of shuttlecock industry employees in Pringgo-layan Village, Surakarta.

H2: Social support influences the work performance of shuttlecock industry employees in Pringgolayan Village, Surakarta.

\subsubsection{Work motivation and employee performance}

Motivation is a desire in someone that causes that person to act. Someone often takes action to achieve a goal. Motivation questions how to encourage the passion of subordinates, so they want to work hard by giving all their abilities and skills to realize company goals.

A person's motivation starts from the need, desire, and drive to act for the achievement of needs or goals. This indicates how strong the drive, effort, intensity, and willingness to sacrifice for the achievement of goals. In this case the stronger the drive or motivation and enthusiasm will be, the higher the performance.

The relationship of work motivation and employee performance in Jayaweera's study found that work motivation has a positive influence on performance, meaning that when employees have high motivation causes employees to be able to optimize their abilities at work [6]. These conditions cause the results of employee work to increase. Work 
motivation is an internal encouragement from employees so that when work motivation is high, employees have a strong commitment and are not easily discouraged in facing various problems at work so that it increases work results. Even though someone has a lot of skills, knowledge, and abilities, the person cannot do a good job until the person can be motivated, so motivation is important in improving employee performance. H3: Work motivation influences the performance of shuttlecock industry employees in Pringgo-layan Village, Surakarta.

H3: Work motivation influences the employee performance of shuttlecock industry employees in Pringgolayan Village, Surakarta.

\subsection{Research framework}

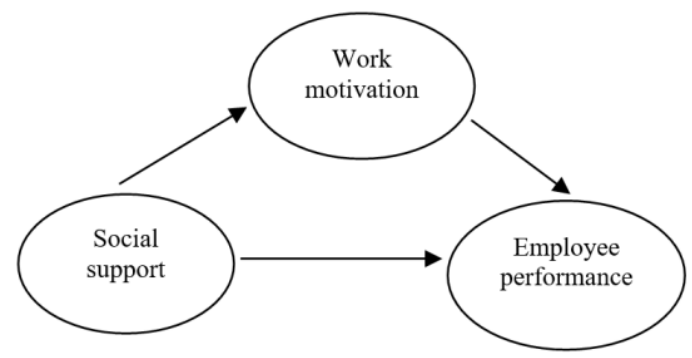

Fig. 1. Research framework

Employees and companies are two inseparable things. Employees play the main role in running the company's life wheel. Within the company, social support is a factor that directly influences work motivation and employee performance. Achieving good performance without getting social support is difficult to materialize. By getting social support employees are able to work more enthusiastically and will ultimately have an impact on improving employee performance. This is what drives employees to conduct research on the effect of social support on employee performance through work motivation.

\section{Research method}

This type of research is quantitative research because this study tests the hypotheses that have been set and to determine the influence of the independent variable (independent) on the intermediate variables and the dependent variable (depen $\neg$ den). This study has the object of social support research (X), employee performance (Y), and work motivation (Z) as intervening variables.

The population in this study are employees of the shuttlecock industry in Pringgolayan Village, Surakarta, totaling 282 people. Determination of the number of representative samples according to Hair good samples for structural equation modeling research is 100200 respondents, where in this study, 100 respondents will be sampled, this number represents the number of active employees working in the last 3 mo [15]. The sampling technique used was purposive sampling, namely the sampling technique with certain considerations [16]. The criterion in this study is that employees must have worked for at least 1 yr.

Operational definitions in this study include research variables consisting of independent or independent variables $(\mathrm{X})$, namely social support, intervening variables $(\mathrm{Z})$, 
namely work motivation and dependent or dependent variables, namely employee performance $(\mathrm{Y})$.

Types and sources of data in this study, using primary and secondary data, where the primary data used in the study was the result of answers from filling out the questionnaire by the respondents. and secondary data used come from literature, literature studies in the form of theories obtained from books, journals, articles, and other sources. Data collection methods used in this study were obtained through a questionnaire. The questionnaire in this study uses a Likert scale. A Likert scale is a "scale used to measure the attitudes, opinions, and pre-conceptions of a person or a group of people about social phenomena [16].The Likert scale used in this study is divided into five categories, from strongly disagree to agree strongly.

In this study, 100 questionnaires were distributed to 100 respondents. The distribution of the questionnaire was done by meeting directly and distributing one questionnaire to respondents who met the sample criteria. This study uses a partial regression analysis technique (Partial Least Square/PLS) to test all proposed research hypotheses. Each of these hypotheses will be analyzed using the SmartPLS 3.0 application to test the effect between variables.

$\mathrm{T}$ test is done to be able to determine the effect of the independent variable partially on the dependent variable, as well as to find out whether the effect was significant or not . The research hypothesis is accepted if $t$-statistic $>t$-table and vice versa are rejected if tcount $<$ t-table.

\section{Analysis and discussion}

In this study, to test the research hypotheses used Parallel Least Square (PLS) analysis with the SmartPLS program. The following are the results of structural model optimization with PLS:

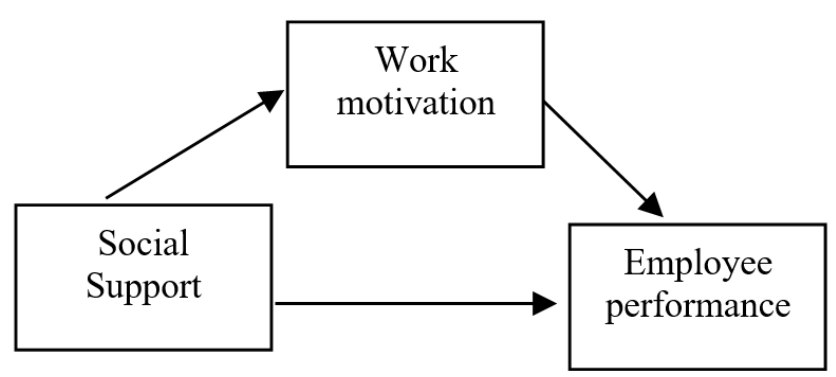

Fig. 2. PLS Path Model

\subsection{Outer model evaluation}

\subsubsection{Convergent validity}

Convergent validity is said to be fulfilled if there is sufficient intercorrelation between variables (indicators) used in measuring the same construct [17]. When the value of the loading out $>0.50$, then the factor is considered to have fulfilled a good convergent validity value. The following is a presentation of the results of calculations that have been done using SmartPLS 3.0 soft ware. 


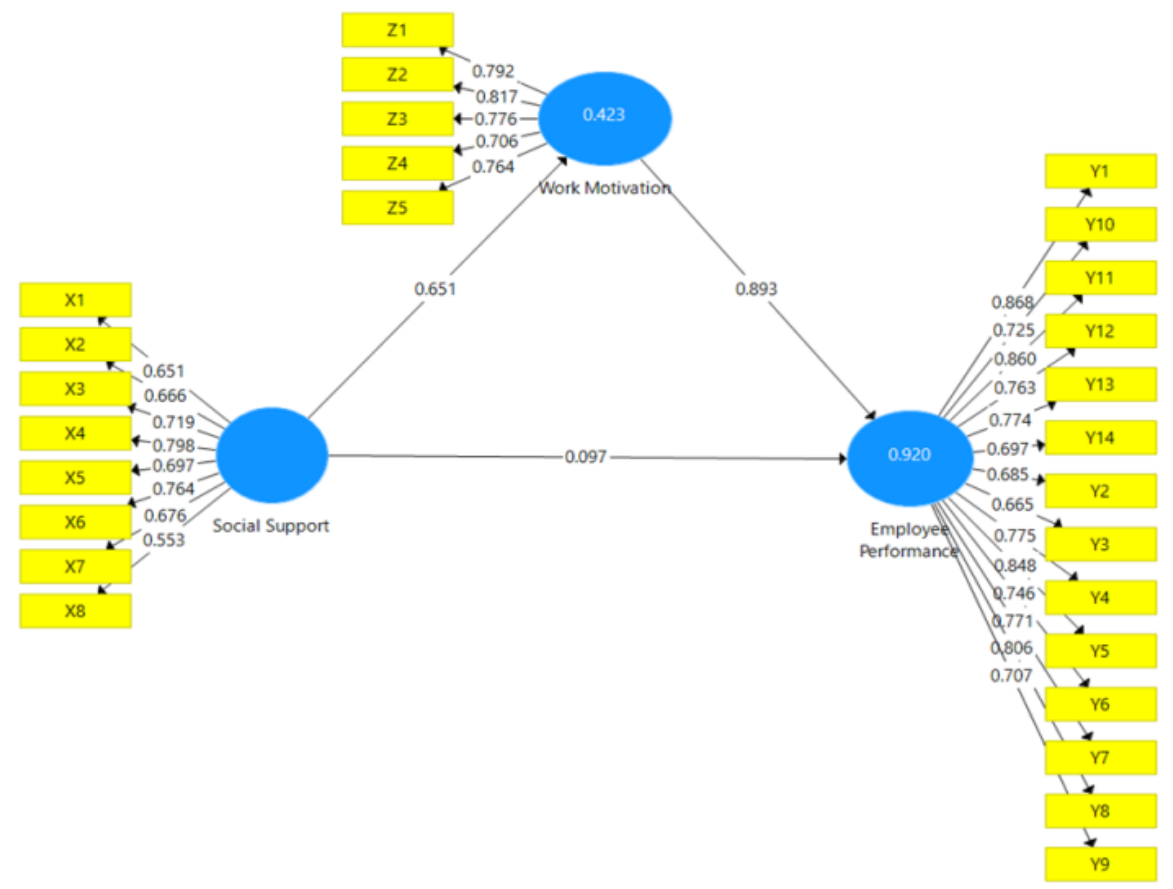

Fig. 3. PLS outer model

Table 1. Outer loading value

\begin{tabular}{cccc}
\hline Variable & $\begin{array}{c}\text { Employee } \\
\text { performance }\end{array}$ & $\begin{array}{c}\text { Social } \\
\text { support }\end{array}$ & $\begin{array}{c}\text { Work } \\
\text { motivation }\end{array}$ \\
\hline X1 & & 0.651 & \\
X2 & & 0.666 & \\
X3 & & 0.719 & \\
X4 & & 0.798 & \\
X5 & & 0.697 & \\
X6 & & 0.764 & \\
X7 & & 0.676 & \\
X8 & & 0.553 & \\
Y1 & 0.868 & & \\
Y10 & 0.725 & & \\
Y11 & 0.86 & & \\
Y12 & 0.763 & & \\
Y13 & 0.774 & & \\
Y14 & 0.697 & & \\
Y2 & 0.685 & & \\
Y3 & 0.665 & & \\
Y4 & 0.775 & & \\
Y5 & 0.848 & & \\
Y6 & 0.746 & & \\
Y7 & 0.771 & & 0.792 \\
Y8 & 0.806 & & 0.776 \\
Y9 & 0.707 & & \\
Z1 & & & \\
Z2 & & & \\
Z3 & & & \\
Z4 & & & \\
Z5 & & & \\
\hline
\end{tabular}

Table 1. shows that the outer loading value for each statement $>0.5$ [18]. This means that it is valid. It also shows that the research instrument used has measured what is supposed to be measured. Thus, the numbers that have been declared valid can be used for further processing at a later stage. 


\subsubsection{Discriminant validity}

Discriminant validity in the reflective measurement model is assessed based on the greater cross loading value compared to other cross loading constructs and AVE (Average Variance Extraxted) with value $\mathrm{s}>0.5$ [19].

Table 2. shows that each construct has a factor loading value > cross loading of another construct. This also shows that each research instrument has measured in accordance with what should be measured so that the numbers that have been declared valid can be used for further processing at a later stage.

Table 2. Discriminant validity (cross loading) value

\begin{tabular}{cccc}
\hline Variable & $\begin{array}{c}\text { Employee } \\
\text { performance }\end{array}$ & $\begin{array}{c}\text { Social } \\
\text { support }\end{array}$ & $\begin{array}{c}\text { Work } \\
\text { motivation }\end{array}$ \\
\hline X1 & 0.5 & $\mathbf{0 . 6 5 1}$ & 0.497 \\
X2 & 0.488 & $\mathbf{0 . 6 6 6}$ & 0.481 \\
X3 & 0.422 & $\mathbf{0 . 7 1 9}$ & 0.405 \\
X4 & 0.545 & $\mathbf{0 . 7 9 8}$ & 0.529 \\
X5 & 0.474 & $\mathbf{0 . 6 9 7}$ & 0.476 \\
X6 & 0.548 & $\mathbf{0 . 7 6 4}$ & 0.503 \\
X7 & 0.404 & $\mathbf{0 . 6 7 6}$ & 0.386 \\
X8 & 0.322 & $\mathbf{0 . 5 5 3}$ & 0.253 \\
Y1 & $\mathbf{0 . 8 6 8}$ & 0.521 & 0.815 \\
Y10 & $\mathbf{0 . 7 2 5}$ & 0.546 & 0.761 \\
Y11 & $\mathbf{0 . 8 6}$ & 0.498 & 0.806 \\
Y12 & $\mathbf{0 . 7 6 3}$ & 0.504 & 0.691 \\
Y13 & $\mathbf{0 . 7 7 4}$ & 0.445 & 0.714 \\
Y14 & $\mathbf{0 . 6 9 7}$ & 0.352 & 0.637 \\
Y2 & $\mathbf{0 . 6 8 5}$ & 0.516 & 0.564 \\
Y3 & $\mathbf{0 . 6 6 5}$ & 0.513 & 0.557 \\
Y4 & $\mathbf{0 . 7 7 5}$ & 0.647 & 0.725 \\
Y5 & $\mathbf{0 . 8 4 8}$ & 0.632 & 0.823 \\
Y6 & $\mathbf{0 . 7 4 6}$ & 0.482 & 0.771 \\
Y7 & $\mathbf{0 . 7 7 1}$ & 0.548 & 0.796 \\
Y8 & $\mathbf{0 . 8 0 6}$ & 0.603 & 0.789 \\
Y9 & $\mathbf{0 . 7 0 7}$ & 0.444 & 0.72 \\
Z1 & 0.731 & 0.443 & $\mathbf{0 . 7 9 2}$ \\
Z2 & 0.762 & 0.525 & $\mathbf{0 . 8 1 7}$ \\
Z3 & 0.782 & 0.558 & $\mathbf{0 . 7 7 6}$ \\
Z4 & 0.71 & 0.432 & $\mathbf{0 . 7 0 6}$ \\
Z5 & 0.7 & 0.542 & $\mathbf{0 . 7 6 4}$ \\
\hline
\end{tabular}

Table 3. AVE

\begin{tabular}{lc}
\hline \multicolumn{1}{c}{ Variables } & $\begin{array}{c}\text { Average Variance } \\
\text { Extracted (AVE) }\end{array}$ \\
\hline Employee performance & 0.587 \\
Social support & 0.582 \\
Work motivation & 0.595 \\
\hline
\end{tabular}

Table 3. shows that all the variables in this study met the discriminant validity criteria, because of AVE > 0.5. This shows that the research instruments used have been measured according to what should be measured. So that the numbers that have been declared valid can be used for further processing at a later stage. 


\subsection{Reliability test}

\subsubsection{Composite reliability}

Composite reliability is used to test the reliability of a variable, which shows the accuracy and consistency of the accuracy of a measuring instrument [17]. A variable is considered reliable if the composite reliability value is more than 0.7 .

Table 4. shows that the composite reliability value of each variable $>0.70$ can thus be said that all research variables have good reliability. It also proves that the response tool is consistent for each variable. Thus the numbers that have been declared reliable can be used for further processing at this stage

Table 4. Composite reliability

\begin{tabular}{lc}
\hline \multicolumn{1}{c}{ Variables } & $\begin{array}{c}\text { Composite } \\
\text { reliability }\end{array}$ \\
\hline Employee performance & 0.952 \\
Social support & 0.880 \\
Work motivation & 0.880 \\
\hline
\end{tabular}

\subsubsection{Cronbach's alpha}

Cronbach's alpha aims to measure the lower limit of the reliability value of a construct [18]. A variable is considered reliable if the value of Cronbach's alpha is more than 0.7 .

Table 5. Cronbach's alpha

\begin{tabular}{lc}
\hline \multicolumn{1}{c}{ Variables } & Cronbach's alpha \\
\hline Employee Performance & 0.945 \\
Social Support & 0.845 \\
Work Motivation & 0.829 \\
\hline
\end{tabular}

Table 5. shows the Cronbach's alpha value $>0.70$, so that all variables in this study have good reliability. This means that the responses of respondents for each variable are consistent, so the figures that have been declared reliable can be used for further processing.

\subsection{Inner model evaluation}

\subsubsection{Goodness of fit - inner model}

This evaluation aims at the ability of the observed value generated by the model and also its parameter estimation. Q-square must be> 0 to show good predictive relevance [19].

Table 6. Determination Coeficient (R Sqaure)

\begin{tabular}{lcc}
\hline & $\begin{array}{c}\text { R } \\
\text { Square }\end{array}$ & $\begin{array}{c}\text { R Square } \\
\text { Adjusted }\end{array}$ \\
\hline Employee performance & 0.920 & 0.918 \\
Work motivation & 0.423 & 0.418 \\
\hline
\end{tabular}

$$
\begin{aligned}
\mathrm{Q}^{2} & =1-[(1-\mathrm{R} 1)(1-\mathrm{R} 2)] \\
& =1-[(1-0.92)(1-0.423)] \\
& =1-[(0.08)(0.577)] \\
& =0.954
\end{aligned}
$$

The Q2 result achieved is 0.954 , meaning that the Q2 value above provides evidence that the model has a relative influence on predictive relevance because the magnitude of Q2 
has a value with a range of $0<0.954<1$, where the closer to 1 means the model is getting better.

Table 6 above gives a value of 0.423 for the construct of work motivation, which means that social support is able to explain the work motivation variance of $42.3 \%$. While giving a value of 0.920 for the construct of employee performance, which means that social support and work motivation is able to explain the variance in employee performance

\subsection{Hypothesis testing}

Hypothesis testing aims to determine the relationships or relationships that occur between each variable studied. In this study, hypothesis testing using a significance value of $5 \%$ with a statistical $\mathrm{t}$ value of 1.985 . Then the hypothesis is accepted when t-statistic $>1.985$.

Table 7. The results of hypothesis testing

\begin{tabular}{lcc}
\hline \multicolumn{1}{c}{ Variables } & $\begin{array}{c}\text { T Statistics } \\
(\mid \mathbf{O} / \text { STDEV } \mid)\end{array}$ & P Values \\
\hline Social Support -> Employee Performance & 2.47 & 0.014 \\
Social Support -> Work Motivation & 12.91 & 0.000 \\
Work Motivation -> Employee Performance & 29.282 & 0.000 \\
\hline
\end{tabular}

Based on Table 7, it can be seen that social support has a significant effect on employee performance, as evidenced by the $\mathrm{t}$ value of $12.91>\mathrm{t}$ table of 1.985, so $\mathrm{H} 1$ is accepted. Based on Table 7, it can be seen that social support has a significant effect on work motivation, as evidenced by the $\mathrm{t}$ value of $2.47>\mathrm{t}$ table of 1.965 so that $\mathrm{H} 2$ is received. Based on table 7 it can be seen that the work motivation has a significant influence on employee performance as evidenced by the $\mathrm{t}$ value of 29.282 , > $\mathrm{t}$ table of 1.985 so that $\mathrm{H} 3$ is accepted

\subsection{The Influence of social support on work motivation}

The results in this study indicate that social support has a significant influence on work motivation; this is evidenced through the $t$ value of $12.91>t$ table of 1.965 . So that shows that social support is one of the factors that influence work motivation.

Another study conducted by Rahmadita found that there was a very significant positive relationship between the social support of a partner to work motivation in female employees [13]. When someone gets full social support for what is done, then people will be more comfortable in working [20]. It enables the person to show maximum work performance, which in turn will increase the work motivation of that person. Employees can be motivated because the majority of the population are working as shuttlecock makers, starting with their parents who work as shut-trick makers and then continuing to their children. So that many young people who also make shuttlecocks to earn their own income, they learn to make shuttlecocks from their parents and their friends.

\subsection{The Influence of social support on employee performance}

This study shows the results that social support has a significant influence on employee performance; this is evidenced through the $t$ value of $2.47>t$ table of 1.965. So that shows that employee performance is influenced by social support. Raeda's study, entitled "Job Stress, Job Performance, and Social Support Among Hospital Nurses," states that social support from colleagues has a significant effect on performance [14]. According to Raeda, 
social support from fellow co-workers can improve the level of employee performance [14].

Social support is an important factor in forming good performance. Social support is an indispensable factor in achieving good performance because with social support, employees are more motivated to work and ultimately able to improve their performance. Social support will encourage employees to work well [2].

\subsection{The Influence of work motivation on employee performance}

Work motivation has a significant effect on employee performance. This is evident from the $\mathrm{t}$ value of $29.282>\mathrm{t}$ table of 1.965 . This shows that employee performance is influenced by work motivation. According to Mensah and Tawiah motivation is a process that takes into account individual intensity, direction and persistence in meeting desired targets [5]. Motivation has psychological and managerial significance. The psychological meaning of motivation refers to a person's internal mental state related to initiation, direction, perseverance, in-tensity and stopping the behavior.

Previous studies results found that work motivation is a factor forming employee performance $[6,21]$. This provides an illustration that motivated employees will be able to work well and be able to complete the work that is a burden. Work motivation is encouragement in employees that can make employees excited at work, thus increasing its performance. Ability, skills and high knowledge, if not accompanied by motivation, will make employees unable to work properly, so motivation is needed in completing a job

\section{Conclusion}

Based on the results of the research and data analysis above, it can be concluded in several conditions. Social support has an influence on work motivation for shuttlecock industry employees in Prainggolan Village, in which high social will be able to increase work motivation significantly. Then, social support has an influence on the performance of shuttlecock industry employees in Prainggolan Village because higher social support will be able to improve employee performance significantly. Finally, work motivation has an influence on employee performance in shuttlecock industry employees in Prainggolan Village as higher work motivation will significantly improve employee performance.

\section{References}

1. Y. Noah, M. Steve, Journal of Sustainable Society, 1,2:36-43(2012). http://worldscholars.org/index.php/jss/article/view/98

2. C.R. Sheridan, S.A. Radmacher, Health Psychology, Singapore: John Willey and Sons Inc (1992). https://www.amazon.com/Health-Psychology-Challenging-BiomedicalModel/dp/047155913X

3. B. Smet, Psikologi Kesehatan. [Health Psychology], Jakarta: PT Grasindo (1994). [in Bahasa Indonesia]. https://opac.perpusnas.go.id/DetailOpac.aspx?id=224028

4. N.J. Olusadum, N. J. Anulika, Journal of Management and Strategy, 9,1:53-65 (2018). https://pdfs.semanticscholar.org/5b75/4442da139595c138ba72a9dfd7cdfd0d7bf8.pdf

5. E.B.K. Mensah, K.A. Tawiah, JIEM 9,2:255-309(2016). http://www.jiem.org/index.php/jiem/article/view/1530

6. T. Jayaweera, International Journal of Business and Management, 10, 3:56-67 (2015). https://pdfs.semanticscholar.org/68a6/677081558f84755557619cdc387377d38abb.pdf 
7. T. Albrecht, M. Adelman, Communicating Social Support. Newbury Park: Sage (1987). https://catalogue.nla.gov.au/Record/1505068

8. F. Kumalasari, L.N. Ahyani, Jurnal Penelitian, 1,4:1-11(2012). [in Bahasa Indonesia]. https://jurnal.umk.ac.id/index.php/PSI/article/view/33

9. A. Suratman, Jurnal Ventur, 1,1:165-188(2003). [in Bahasa Indonesia]. https://media.neliti.com/media/publications/44239-ID-korelasi-antara-pengembangankarir-dengan-motivasi-kerja-dan-keinginan-untuk-pen.pdf

10. Wursanto, Dasar-Dasar Ilmu Organisasi. [Fundamentals of Organizational Sciences.], Yogyakarta: Andi Offset (2003). [in Bahasa Indonesia]. http://andipublisher.com/produk-0501001256-dasardasar-ilmu-organisasi.html

11. S. Torang, Organisasi dan Manajemen Perilaku, Struktur, Budaya \& Perubahan Organisasi. [Organizational and Management Behavior, Structure, Culture \& Organizational Change], Bandung: Alfabeta (2013). [in Bahasa Indonesia]. http://perpustakaan.kasn.go.id/index.php?p=show detail\&id=53\&keywords=

12. Sedarmayanti, Manajemen Perkantoran Suatu Pengantar [Office Management An Introduction], Bandung: Mandar Maju (2001). [in Bahasa Indonesia].

13. I. Rahmadita, eJournal Psikologi, 1,1:58-68(2013). [in Bahasa Indonesia]. http://ejournal.psikologi.fisip-unmul.ac.id/site/wpcontent/uploads/2013/04/JURNAL\%20DITA\%20PDF\%20(04-04-13-09-33-04).pdf

14. R.F. AbuAlRub, J. Nurs. Scholarsh., 36,1:73-78(2004). https://www.ncbi.nlm.nih.gov/pubmed/15098422

15. J.F. Hair, W.C. Black, B.J. Babin, R.E. Anderson, Multivariate Data Analysis. New Jersey: Pearson Prentice Hall (2006). https://www.pearson.com/us/highereducation/program/Hair-Multivariate-Data-Analysis-7th-Edition/PGM263675.html

16. Sugiyono, Metode Penelitian Kuantitatif, Kualitatif, dan R\&D. [Quantitative, Qualitative, and R\&D Research Methods], Bandung: Alfabeta (2018). [in Bahasa Indonesia].

https://scholar.google.com/scholar?hl=en\&as_sdt=0,5\&cluster $=103286501906575880$ 78

17. H.M. Jogiyanto, W. Abdilah, Partial Least Square (PLS) alternatif SEM dalam penelitian bisnis. [Partial Least Square (PLS) alternative SEM in business research], Yogyakarta: Andi (2009). [in Bahasa Indonesia]. http://andipublisher.com/produk0715005812-partial-least-square-pls-alternatif-stru.html

18. I. Ghozali. Structural Equation Modeling Metode Alternatif dengan Partial Least Square (PLS). [Structural Equation Modeling Alternative Methods with Partial Least Square (PLS)], Semarang: Badan Penerbit Universitas Diponegoro, (2011). [in Bahasa Indonesia]. https://digilib.undip.ac.id/v2/2012/10/04/structural-equation-modelingmetode-alternatif-dengan-partial-least-square/

19. C.E. Cutrona, D.W. Russell. Journal of Personality and Social Psychology, 1,1:3767(1987).

https://www.researchgate.net/profile/Daniel_Russell4/publication/271507385_The_Pr ovisions_of_Social_Relationships_and_Adaptation_to_Stress/links/54c960b40cf2807 dcc265ce2/The-Provisions-of-Social-Relationships-and-Adaptation-to-Stress.pdf

20. O. Stella, Motivation and Work Performance; Complexities in Achieving Good Performance Outcomes; A Study Focusing on Motivation Measures and Improving Workers Performance in Kitgum District Local Government. [Thesis]. Graduate School of Development Studies, Hague, Netherlands (2008). https://thesis.eur.nl/pub/7156/Stella\%20Opu\%20HRE.pdf

21. F. Christyoadi, Sukarti, M.F. Suseno, Hubungan antara dukungan sosial dengan motivasi kerja karyawan PT. Usmantek Kabupaten Magelang. [The relationship between social support and work motivation of employees of PT. Magelang Regency Usmantek], [Undergraduate Thesis]. Fakultas Psikologi dan Ilmu Sosial Budaya, 
Universitas Islam Indonesia, Yogyakarta (2009). [in Bahasa Indonesia]. https://dspace.uii.ac.id/bitstream/handle/123456789/4667/02\%20preliminari.pdf?sequ ence $=2 \&$ is Allowed $=y$ 